\title{
Managing multilingualism on state websites: How institutional employees explain language choice
}

The purpose of this study is to understand how institutional language managers make and legitimize decisions about language choice on state websites. The focus lies on state institutions in two technologically advanced European nation-states: Estonia and Norway. The analysis is empirically based on interviews with employees at the institutions, who are involved in the implementation and appropriation of state language and communication policies. A qualitative study focusing on these language managers helps to reveal the way they make sense of their policy environment, and brings out their priorities and challenges. The interview data show that institutional language managers explain language choice not just by referring to explicit policy statements, but also in relation to a broad range of other factors, such as economic, pragmatic, and technical considerations. The article sheds light on the language ideologies underpinning these factors by demonstrating how various languages are valorized differently in the institutions and reveals a complexity of intertwined reasons behind the prioritization of certain languages over others. Finally, the article aims to show that it is important to go beyond analyzing policy documents and websites as finished products, and to talk with the institutional actors in order to gain insight into the multiple conditions that influence language policy.

Keywords: Norway; Estonia; language management; language managers; state websites; language policy; language ideologies.

\section{Introduction}

Language management at the state level includes the organization of public sector communication with groups who may speak many different languages. In technologically advanced countries, this communication has now to a large degree moved to cyberspace, and for most citizens who have the necessary digital literacy, hardware, and Web access, the most direct route to the relevant authorities lies via the Internet. State websites have become a central platform for the provision of state information to the people and are therefore a promising arena for studying language policy and language management. This new media environment is subject to various (and often conflicting) language ideologies, practical considerations, and technical limitations. There is no 
doubt that governments are central policy makers that decide about which language(s) to legitimate, promote, or omit in official state communication. However, while the use of different languages on public sector websites is regulated by official legislation created by the state itself, state institutions comprise people who appropriate these policies according to the current institutional needs and who are familiar with the practical challenges connected to managing multilingual websites. This article aims to show how it is important to go beyond analyzing policy documents and websites as finished products, and to talk with the institutional language managers (Spolsky 2004; 2009) in order to investigate why and under what conditions certain languages are included or omitted. Such a focus helps to discover which language ideologies underpin the decision making around language choice in the management of multilingual state websites.

The purpose of this study is to understand how institutional language managers make and legitimize decisions about language choice on state websites. The analysis is empirically based on semi-structured interviews with people who in their everyday work deal with state communication with the public in cyberspace. A qualitative study focusing on the perspectives of language managers in state institutions helps to reveal how they make sense of official state policies, and exemplifies their reasoning behind policy appropriation to more local, institutional needs. Furthermore, it brings out their explanations regarding state communication in languages, where the use of these languages is not explicitly regulated by official legislation. Taking this focus helps 'to illustrate convergences and divergences between top-down government aspirations and the perceptions and lived ideologies' (Barakos, 2012, p. 173) of the people who work with state communication in practice. I draw on data from two technologically advanced European nation-states - Estonia and Norway - and analyze the way individual employees who are involved in the management of multilingualism in the context of top-down regulated online state communication, explain and to a certain extent justify their choices. These institutional actors are language managers who implement and appropriate official language and communication policies in the institutional context and can shape policy decisions to particular contextual demands (Johnson \& Johnson, 2015, p. 223).

I argue that explanations by the state employees regarding language choice can point to broader language ideologies in the nation-state. The article broadly adopts a critical approach to language policy (Johnson, 2011; Tollefson, 2006), seeing language ideologies and asymmetrical power relations in society as important in the investigation of language policy processes. 
According to Blackledge (2005, p. 32), language ideologies constitute 'values, practices and beliefs associated with language use' and are 'produced in discourses' (Blackledge, 2005, p. 44) at the local, regional, national, and supranational level. In this way, the justifications and sensemaking of the language managers regarding the use of different languages on state websites can shed light on the underlying language ideologies, which convey beliefs about the value and functions of languages (Pietikäinen \& Kelly-Holmes, 2013, p. 8).

The article proceeds as follows. First, the theoretical framework for this study is outlined. This is followed by an overview of the contextual background, with a focus on the linguistic situation, central language policies for state communication, and language use on state websites in Estonia and Norway. I then proceed to presenting the study and its results. The explanations by the participants are illustrated in the form of two models, which provide an overview of the complexity of reasons behind managerial decisions about the use and non-use of various languages on public sector websites. Lastly, I discuss the broader language ideologies that become evident through the participants' explanations of language choice, and explore the implications of the study for researching language policy in institutional contexts.

\section{Theoretical underpinnings: A focus on language managers}

The state as the creator of official policies is only one, although a very central, actor among many that define language norms and regulate language use in contemporary globalized societies (Blommaert et al., 2009). In reality, policies are 'created across multiple layers of context and institutional authority' (Johnson, 2015, p. 172), including meso-level actors such as institutions, and also individual actors. Ricento and Hornberger (1996) use the metaphor of an onion in order to describe the multiplicity of layers and contexts through which language policies develop, with each layer containing its own agents. A perennial challenge in the study of language policy is making connections between the macro and the micro, or 'between the multiple layers of language policy creation, interpretation, and appropriation' (Johnson, 2011, p. 267). A number of researchers have taken an ethnographic approach (Hornberger \& Johnson, 2007) to researching language policy, in order to make better sense of the beliefs, perspectives, and practices of language policy agents (see for example Barakos, 2012; McCarty, 2011; Siiner, 2016). 
Ethnographic and other qualitative work focusing on language policy agents helps to reveal the ways they make sense of their policy environment, and how they interpret and appropriate language policy regulations in sometimes unpredictable ways (Johnson, 2011, p. 269).

The term 'language management', initially introduced by Jernudd and Neustupný (1987) as a novel continuation of the language planning tradition, has become a widely used expression in the sociolinguistic literature. As pointed out by Sanden (2016, p. 521), today 'the question is not whether the term is in use or not, but rather by whom, and in what way'. Sanden (2016) highlights three research traditions of language management that differ substantially in their approach. He argues that language management may refer to:

(1) The Language Management Theory (LMT), which developed along the lines of what was initially proposed by Jernudd and Neustupný (1987). According to the LMT, language management is a corrective discourse-based process and involves the generation of utterances and the management of these utterances (see e. g. Nekvapil 2006; Nekvapil \& Sherman 2015). Importantly, the management process only starts when a deviation from an established norm is noted (Nekvapil \& Sherman 2013: 91). Central to the LMT is the division between simple (discourse-based, face-to-face) and organized (institutional) language management, which are at the same time seen as interconnected.

(2) A sub-concept of Spolsky's language policy model. According to Spolsky $(2004 ; 2009)$, language management is one of the three components of language policy alongside with language practices and language beliefs, and refers to the explicit and observable efforts by someone or some group to modify or influence language practice or beliefs. Importantly, Spolsky (2009) only identifies language management when it is possible to identify the language manager.

(3) A variable in business and corporate management. According to this definition, language management is first and foremost an instrumental approach and has as its primary goal to facilitate efficient corporate communication (Sanden 2016, p. 526).

The current study adopts Spolsky's definition of language management and sets the focus on language managers. According to Spolsky (2004), language management is to be interpreted as a manipulation of the language situation of a community, and language managers hold a central position in this process. Under Spolsky's (2004) definition, all those involved in language management through seeking to modify the language situation in any way are language managers. They are portrayed on a continuum from families and individuals to institutions and businesses, 
local government bodies, and national assemblies. In the context of this study, language managers can be identified both on the level of the state (individuals, groups, and public bodies involved in the creation of official policies) and on the more local institutional level (individuals responsible for the interpretation and appropriation of the policies in the context of the specific institutions). This article refers to employees involved in institutional language management as language managers and demonstrates their challenges in choosing communication strategies and making compromises in realizing the policies. Such institutional decisions are not entirely based on official regulations but can be further influenced by local communicational goals and even by personal judgments, as the perceived value of a language can be a major force in driving language management (Spolsky, 2009, p. 64).

Spolsky (2009: 226) further emphasizes the importance to distinguish between the individuals and agencies that are established specifically to deal with language management and the ones that 'include language management within the wider responsibilities of the agency'. The state institutions in focus in this article belong to the latter type of agencies named by Spolsky: although controlling and prescribing language choice is not a direct aim of these institutions, it nevertheless happens, even if unconsciously and unplanned, in the course of language management of multilingual state communication. Spolsky (2012) outlines an example of language management which takes place through the encouragement or forcing of members of a speech community to use a different language variety or variant, and this can, to a certain degree, be seen to be the case in the regulation of language choice and use on state websites. In the context of this article, language management can be seen as a goal-directed activity to get a task done, which is not necessarily directly about language but involves language choice. The overarching task of public sector institutions can be seen as disseminating information (for instance, about welfare benefits or tax regulations), and communicating with the multilingual public. While influencing language practices among the public is not the direct aim of these institutions, it nevertheless takes place in the course of language management. More specifically, it happens through granting online visibility to some languages, and through the erasure (Irvine \& Gal, 2000) of others from state websites.

\section{Background of the study}




\section{DRAFT - Please do not cite}

Norway and Estonia illustrate two different sociolinguistic situations in the European sphere of democratic norms, allowing for an investigation of challenges in state communication with various types of linguistic minorities. At the same time, both Norway and Estonia are influenced by globalization trends, which in this case manifest in the widespread use of English in online state communication. In recent years, Estonia has been at the forefront of digital public services in Europe, and also Norway is performing very well when compared to the average in the European Union (European Commission, 2016). Drawing on data from two countries helps to demonstrate a broad variety of reasons behind the creation of the covert language policy, and also to show how language managers assign different priorities to these reasons depending on the contextual demands. I will now briefly outline the linguistic situation and legislation regarding language use in the public sector in Estonia and Norway (for a more detailed overview, see Berezkina, 2015; Berezkina, 2016).

Norwegian has two written standards: Bokmål and Nynorsk. The two standards have equal status in Norway; however, Nynorsk is only used by around 10-15\% of the population (see Grepstad, 2015; Mæhlum, 2007; Røyneland, 2013 for an overview of the language situation in Norway). Norway has implemented the provisions of the European Charter for Regional or Minority Languages, with protection granted to Sámi, Kven, Romanes, and Romany. The Sámi have furthermore been recognized as indigenous people in Norway and are entitled to special rights and protection. Official language legislation in Norway regulates the use of Sámi and Nynorsk in state communication. According to the Language Act (Mållova, 1980), none of the two written standards of Norwegian should be used by less than $25 \%$ in written publications issued by state institutions, and this also includes websites. The use of Sámi in official communication is required by the Sámi Act (Sameloven, 1987) and also emphasized in the Central Government Communication Policy (2009). Finally, around 16.3\% of Norway's total population of 5.2 million has immigrant background from a large number of countries (Statistics Norway, 2016). The use of immigrant languages in state communication is not regulated by any official legislation. At the time when this study was conducted, the websites of the three state institutions in focus used Bokmål, Nynorsk, Sámi, and English. All three institutions had previously attempted to include numerous immigrant languages to their websites, but almost all of these languages were removed in 2014 (Berezkina, 2016). 
The main immigration source in Estonia is connected to the Soviet period. As a result, L1

Russian speakers (mostly Russians, Belarusians and Ukrainians) constitute the largest minority group in the country, which makes the demographic situation in Estonia more homogeneous than in Norway. At the time of the latest census in 2011, Russian speakers constituted $29.6 \%$ of Estonia's total population of 1.3 million people (Statistics Estonia, 2016). However, Estonian has been the single official language of the country since the restoration of independence in 1991, while Russian has not been officially recognized as a minority language. Language legislation in Estonia is mostly concerned with supporting and strengthening Estonian as the sole national language. This must, of course, 'be seen against the historical background of the compulsory official bilingualism of Soviet times', which served the covert goal of Russification of Soviet republics (Laakso \& Sarhimaa, 2016, p. 73). According to the Language Act (2011), Estonian is the only official language of the country, and the language of public administration. Despite the absence of Russian from official legislation, in reality public services accommodate Russianspeakers to a large degree. It is typical for state websites to be trilingual in Estonian, Russian and English (Berezkina, 2015), and this is also the case with the four institutions in focus in this article.

\section{Data and method}

The data presented in this study were collected in 2014 and are part of a broader research project on language use in online and offline state communication in Estonia and Norway. All together 8 state employees participated in the study. In Norway, I conducted interviews in three state institutions: the Directorate of Immigration, the Tax Administration, and the Labour and Welfare Administration - with one individual interview per institution. In the Estonian case, I conducted interviews in the following four institutions: the Police and Border Guard Board (two single interviews), the Tax and Customs Board (one joint interview with two people), the Social Insurance Board (one single interview), and the Unemployment Insurance Fund (one joint interview with two people). The different number of institutions per country was a result of the fact that the Norwegian Labour and Welfare Administration covers to a great extent the functions 
of the Estonian Social Insurance Board and Unemployment Insurance Fund. The number of people per interview session was decided by the interviewees themselves.

The participants were selected deliberately for this study, based on their professional profile as people who in their everyday work deal with language management in their institution's communication with the public, whether both online and offline, or only online. A typical professional profile was that of the communication director, head of section for communications, senior specialist for external communication, web editor, or content manager. I first contacted the participants per e-mail, aiming to get in touch with the top-level employees whose responsibilities include among other things decision-making regarding online communication. Not all the people to whom I wrote replied to the e-mail, and others suggested another person as better suited for the study. All participants provided informed consent, and I agreed to their anonymity, hence their names and full professional titles are not mentioned in this article.

The interviews facilitated the discussion of the participants' experiences in institutional communication with a multilingual public and in the implementation and/or appropriation of language and communication policies. The main topics of the interviews were the following: a) the procedure of creating websites in different languages and the reasons behind the specific linguistic and content related choices; b) the importance of online communication with the public for the institution; c) the use of different languages in the institution's call centers and client service centers. The participants were, among other things, asked about the details of managing a multilingual website on a daily basis, and about the importance of official legislation for the covert language policy in the institutions' communication with a multilingual public. The total recorded interview time was 5 hours and 55 minutes. The interviews were conducted in Norwegian and Estonian respectively, and parts of them were translated for this article by the present author. Prior to the interviews, I conducted an analysis of language use on the websites of the institutions in focus, which was mapped mainly on two levels of the website architecture: the front pages and pages to which links were provided on the front pages. The questions in the interview guide were designed taking into consideration the website data collected.

The interview data were analyzed using the method of qualitative content analysis, following the procedure suggested by Dörnyei (2007, p. 246): (a) transcribing the data, (b) manual coding, (c) growing ideas in the form of memos, and (d) interpreting the data and drawing conclusions. In this article, the focus lies on explanations regarding the use or non-use of certain 
languages on state websites. Since the analysis of the interview data was mainly non-linguistic and explored content and themes rather than the participants' discursive practices, I used orthographic transcription following the rules of standard Bokmål and Estonian. In order to create a categorization of the various explanations for the online language policy that was current at the time of the interviews (in 2014), I first analyzed the full transcripts of the interviews and listed all possible explanations that the participants provided, categorized by language. In the process of coding, I searched for patterns throughout these explanations, as a way of finding more general tendencies in the material and see the connections across the individual interviews, institutions, and countries. In order to make sense of my data, I created coding maps with categories for the different reasons and justifications used by the institutional language managers. An overview of the different types of explanations is provided in the sections below in the form of two models derived from the coding maps. The participants' perceptions and experiences are exemplified throughout the article by interview excerpts, which are considered most representative and relevant for the discussion.

\section{Explanations of language policy on state websites}

Below follows an overview of the language managers' explanations regarding the institutional language policy for online communication with the public, which I derived from the interview data from Estonian and Norwegian state institutions. The explanations are presented in the form of two models: Figure 1 outlines the reasons for the inclusion of different languages on state websites, and Figure 2 gives reasons for their exclusion. As will be demonstrated further below, explanations regarding the exclusion of languages from state websites were only found in the interview data from Norway. This can be partially explained by the fact that recent changes entailed the removal of immigrant languages from the websites in focus, and this was therefore a central topic in the interviews.

The two proposed models are designed to show the multitude of reasons that language managers draw on in order to explain the online institutional language policy. These reasons are otherwise not visible in the processes of language policy and planning. Therefore, an overview of the different explanations is useful as it moves the focus on from an analysis of the use or non-use 
of particular languages on state websites to a broader discussion of the reasons and ultimately underlying ideologies behind decisions about institutional language policy. It is important to point out that some of the categories are more extensive than others, and they refer to more examples than others. Certainly, there may be more categories, and this overview is by no means meant to be static or exhaustive. Finally, it must be emphasized that the presence or absence of one particular language can be explained by multiple intertwined reasons, and there are no rigid borders between the categories.

\subsection{Explaining inclusion}

The model below (Figure 1) is based on the interviews with institutional language managers in Norway and Estonia. Each proposed category is further illustrated and discussed in the following sub-sections.

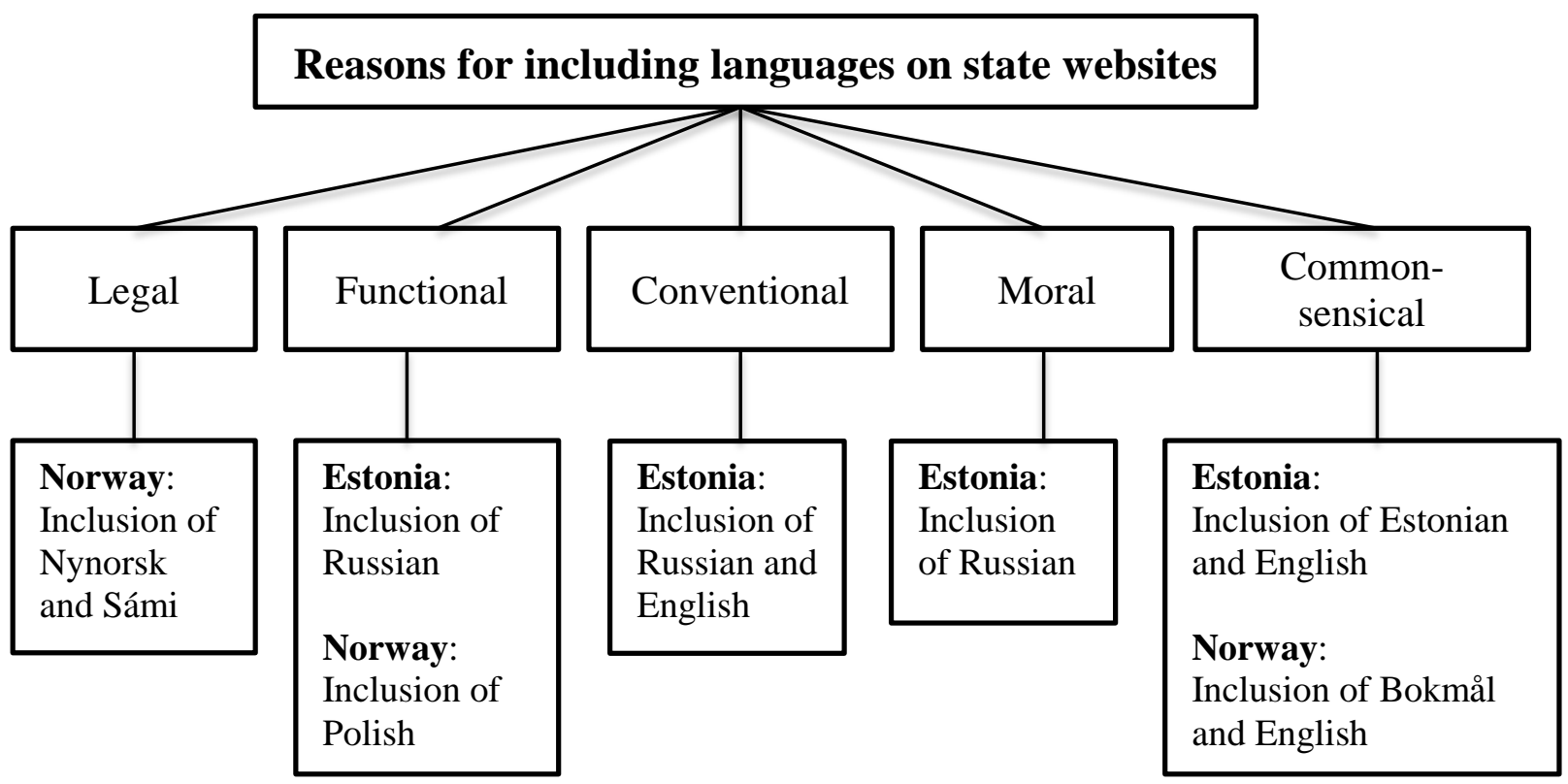

Figure 1. Overview of the reasons provided by language managers in Estonian and Norwegian state institutions in order to explain the presence of various languages on the institutional websites.

(a) Legal reasons. This category comprises the explanations regarding the presence of a language on a state website by reference to the official legislation. These were salient in the Norwegian case, namely in connection to Nynorsk and Sámi. In fact, producing web content in 
Nynorsk and Sámi was explained solely by the fact that their presence on state websites was required by official legislation. Typical examples of explanations by referral to official legislation included expressions like 'we are required to', 'we must', 'it's a rule', and 'according to [Law]'. For example, this is how the participant in the Labour and Welfare Administration explained the presence of Sámi (first excerpt) and Nynorsk (second excerpt) on their website:

Vi er jo pålagt, og vi er jo en av de institusjonene som man har satt ganske klare føringer til.

Well, we are required [to do this], and we are one of the institutions that has received quite clear guidance regarding this.

Altså nynorsk er jo greit, det er en regel, sånn at tjuefem prosent skal være på nynorsk.

Well, when it comes to Nynorsk, then it's okay, it's a rule, so that twenty-five percent must be in Nynorsk.

The organizations and people advocating for Sámi and Nynorsk were repeatedly referred to as 'the other' in the interviews:

Disse menneskene med samisk er jo sånn 'bare oversette mer og mer', men vi tenker at det har ikke noe hensikt hvis det ikke blir brukt da.

Those people with Sámi are like 'just translate more and more' but we think that there is no purpose if it is not used. (Labour and Welfare Administration)

Dem ønsker at de skal bli likeverdige språk.

They wish that they [Bokmål and Nynorsk] would become equal languages. (Directorate of Immigration)

When it comes to the latter quote, it should be mentioned that Bokmål and Nynorsk already are, officially, equal language varieties, and have in fact had equal status in Norway since 1885, based on a parliamentary resolution. However, the real position of Nynorsk in official services and bureaucracy remains weak (Grepstad, 2015).

It is of crucial importance that the reason for the presence of Sámi and Nynorsk on state websites tended to only be presented as something required by the law. The fact that this was the most used explanation indicates that it may be typical for the state institutions in Norway to create these language versions because they have to, rather than because they are engaged in enhancing 
the status of Sámi and Nynorsk in official communication. Koskinen (2013) emphasizes the symbolic value of translations, especially in the case of smaller languages when the role of translation can rather be seen as 'a monument' than as a means of communicating anything to anyone. To a certain degree, this can be seen as the case here, and all the Norwegian participants treated translations into Sámi and Nynorsk as a challenge and a difficult goal to reach. The presence of these languages in online state communication without the legal protection would be highly questionable. Importantly, none of the institutions have in fact reached the goal of Nynorsk composing $25 \%$ of the text on their websites. Several other studies (Indrebø Ims, 2007; Simonsen Thingnes, 2015) have brought attention to the low prioritization of Nynorsk in Norwegian institutions. This situation inevitably raises questions about the position of Nynorsk and Sámi on the Norwegian linguistic market (Bourdieu, 1991), and highlights ideological tensions between the official legislation and the value of these languages as perceived by the language managers.

(b) Functional reasons refer to explanations by reference to the practical necessity of translating a website into a certain language. Ideological, social, and historical factors all play a part in the complexity of decision-making, but so too does practicality. It was regularly pointed out in the interviews that with regard to some groups, sometimes institutions just 'have to' provide information. This is especially manifested in the Estonian case, where functional arguments were presented when explaining the use of Russian on state websites despite a Language Act with a monolingual focus. A typical position of the language managers can be illustrated by a quote from the participant in the Unemployment Insurance Fund:

Me siin ei jälgi riigi keelepoliitikat, me lähtume oma eesmärgist ja otstarbekas on inimestele infot jagada nende emakeeles.

We don't follow the state language policy here, we proceed from our goal and it's efficient to provide people with information in their mother tongue.

The widespread use of Russian in the Estonian public sector and the way institutional actors support it, illustrates the significant gap between official language policy and real-life institutional practices (Berezkina, 2015). Institutional language practices can transform state language policy, 'sometimes merely localizing, sometimes challenging or subverting it' (Androutsopoulos, 2009, p. 286; see also Spolsky, 2009, p. 228). In this way, institutions hold agency and can create what can be recognized as a language policy, 'one that is not directly the 
result of some larger macro policy, but is a response to their own needs, their own "language problems", their own requirement for language management' (Baldauf, 2006, p. 155).

In the Norwegian case, the functional explanation was used by the participant in the Tax Administration for justifying the presence of Polish on an additional website connected to the institution. Today, Poles constitute the largest immigrant group in Norway, and a significant part of them are labor immigrants who pay taxes and have rights to social welfare (Statistics Norway, 2016). Poles are therefore an important target group for the Tax Administration, and the institution has maintained a separate website with key information in Polish since 2009.

Vi har sett at det er mange polske som kommer og jobber i Norge, så vi lagde et nettsted som heter taxnorway. [...] Så det var jo på en måte en vurdering ut fra at her er volumet stort, og det er vedvarende ikke sant, vi så ikke noen tendenser på at det gikk ned i hvert fall, men det holdt seg stabilt.

We have seen that there are many Poles who come and work in Norway, so we created a website that is called taxnorway. [...] So this was in a way an assessment based on the fact that the volume is large here, and it is persistent right, we did not see any tendencies that it was going down at least, but it remained stable.

In the cases of Russian in Estonia and Polish in Norway, we can thus see how sometimes a language, the use of which is not required by any official legislation, can become an important asset for state institutions. As pointed out by Kochenov and de Varennes (2015), 'state institutions are "more efficient" when they operate in the language(s) actually understood or mastered by the population of a country' (p. 59). In such cases, a budget is allocated for translation, as these languages seem to be regarded as 'a resource' (Ruíz, 1984) - for example, for generating tax revenues - in state communication.

(c) Conventional reasons. This type of explanation rests on the principle that something can be considered a reasonable practice if others who are similar to you behave in the same way. For example, one of the participants from the Estonian Tax and Customs Board said the following when explaining the institution's language policy:

See on siiski Eesti puhul suht tavapärane, et riigiasutuste ja ka äride kodulehed on ikka kolmes keeles.

It is, however, quite typical for Estonia that the home pages of state institutions and also businesses are in three languages. 
This type was only found in the Estonian material, when participants explained the language choice on the trilingual Estonian-Russian-English website of their institution as typical also for other institutions in the country. This points to a tendency that the use of both Russian and English in the Estonian institutional cyberspace is accepted as something normal. Such an attitude is also central for the Strategy of Integration and Social Cohesion in Estonia 2020 (Ministry of Culture 2014), which supports the use of Russian on web portals that communicate everyday practical information.

(d) Moral reasons. This category refers to explanations regarding the creation of a language version of a website because the L1 speakers of this language 'deserve' to receive information which they can understand fully. This type was found in the case of one institution in Estonia (Social Insurance Board). The participant explained the fact that the institution creates an almost full translation of their website in Russian by talking about the rights of the L1 Russian speakers in Estonia to receive state information in their mother tongue:

Meie näeme küll, et kogu meie asjaajamisel vene keel moodustab päris suure osa ja inimestel peab olema võimalus pöörduda vene keeles, et saada aru, millist hüvitist neil on õigus saada. Nad on sotsiaalmakse maksnud, neil on õigus hüvitist saada, järelikult on neil ka õigus informatsiooni saada[...]. Seda on ka meie kodulehest näha, et meil vene keel peaks olema ikka samas mahus kui eesti keel.

We see indeed that in all our activities, Russian constitutes quite a big part and people must have a possibility to contact us in Russian in order to understand what kind of compensation they are entitled to. They have paid social security taxes, they have the right to receive compensation, and consequently they have the right to receive information [...]. This can also be seen from our website, that we should have Russian to the same extent as Estonian.

Such reasoning illustrates a positive attitude towards the use of Russian in state communication in Estonia, in order to grant Russian L1 speakers better access to the public sector. Together with the 'conventional' reasons, it shows an attitude among the language managers (and perhaps in the Estonian society more generally) of having transcended the view of seeing Russian as a threat for the Estonian language.

(e) Commonsensical reasons. Finally, I refer to the so-called 'commonsensical reasons' in order to best describe how the use of Estonian and Bokmål (the majority written standard of Norwegian), as well as of English on state websites was taken for granted in the participants' explanations. The participants in the study accepted the use of these languages on public sector 
websites in Estonia and Norway as something normal and routine. When the use of a language is taken for granted in a particular setting, or when its hegemony is not problematized or even discussed, we are dealing with implicit language management (Schiffman, 1998). This is different from rendering a social action normal or natural (see for example Vaara, Tienari, \& Laurila, 2006), as there are no explicit explanations involved.

While the appearance of non-majority languages on state websites is marked, the use of Estonian and Bokmål is not marked. Their online prominence is therefore seen as something natural or logical and was not thematized in the interviews. The use of English on state websites was not questioned by any of the participants either. In the globalized world, it has become 'natural' to have a version of a website in English, the lingua franca of the information age. The use of English on websites has become a common-sense assumption for numerous reasons, such as English being the language of technology and modernity, the global choice (Kelly-Holmes, 2014), and the neutral choice, although of course its usage and heritage are far from neutral (Pennycook, 2014). Importantly, the construction of English as a global language and its iconization as the language of Internet and technology can serve as a powerful justification for the full or partial absence of online translations into minority languages.

\subsection{Explaining exclusion}

The model in Figure 2 is based on the interviews with institutional language managers in Norway only, as no instances of explaining language exclusion from state websites were found in the data from Estonia. The topics of why there is no information in the regional languages Võro or Seto, or in the languages of new immigrants who do not speak Russian, were not part of the interview guide and were not brought up by the interviewees either.

Estonia has neither signed nor ratified the European Charter for Regional or Minority Languages and defines Võro and Seto spoken in Southern Estonia as 'dialect languages' (murdekeel in Estonian) (see Rannut, 2008; Verschik, 2005). According to the Language Act (2011), Võro and Seto can be used alongside standard Estonian in official texts in their traditional

regions; however, the use of these 'dialect languages' is perceived as more locally oriented and not suitable for being used on state websites. 
As for the use of immigrant languages on state websites in Estonia, it should be mentioned that in 2014, when the interviews were conducted, the number of immigrants to Estonia amounted to 4000. However, most of them were returning migrants, while most new immigrants arrived from Russia and Ukraine (Statistics Estonia, 2016). At the time of the 2011 census, 68.5\% of Estonia's population spoke Estonian as their first language, while Russian was the mother tongue of $29.6 \%$, leaving less than $2 \%$ for other languages spoken as mother tongues (Statistics Estonia, 2016). In parallel to the 'commonsensical' reasons described in the previous section for using certain languages online, we could see the absence of this topic as an indicator that the use of other languages than Estonian, Russian and English online is not (yet) even an issue to consider for the language managers in the Estonian state institutions. This is notably different from the Norwegian case, where immigration from a large number of countries is much more significant, and also an older phenomenon (more precisely, from the end of 1960s; Statistics Norway, 2016). Importantly, all three Norwegian state institutions in focus had previously tried adding immigrant languages to their websites, even though this was and is not required by any official regulation.

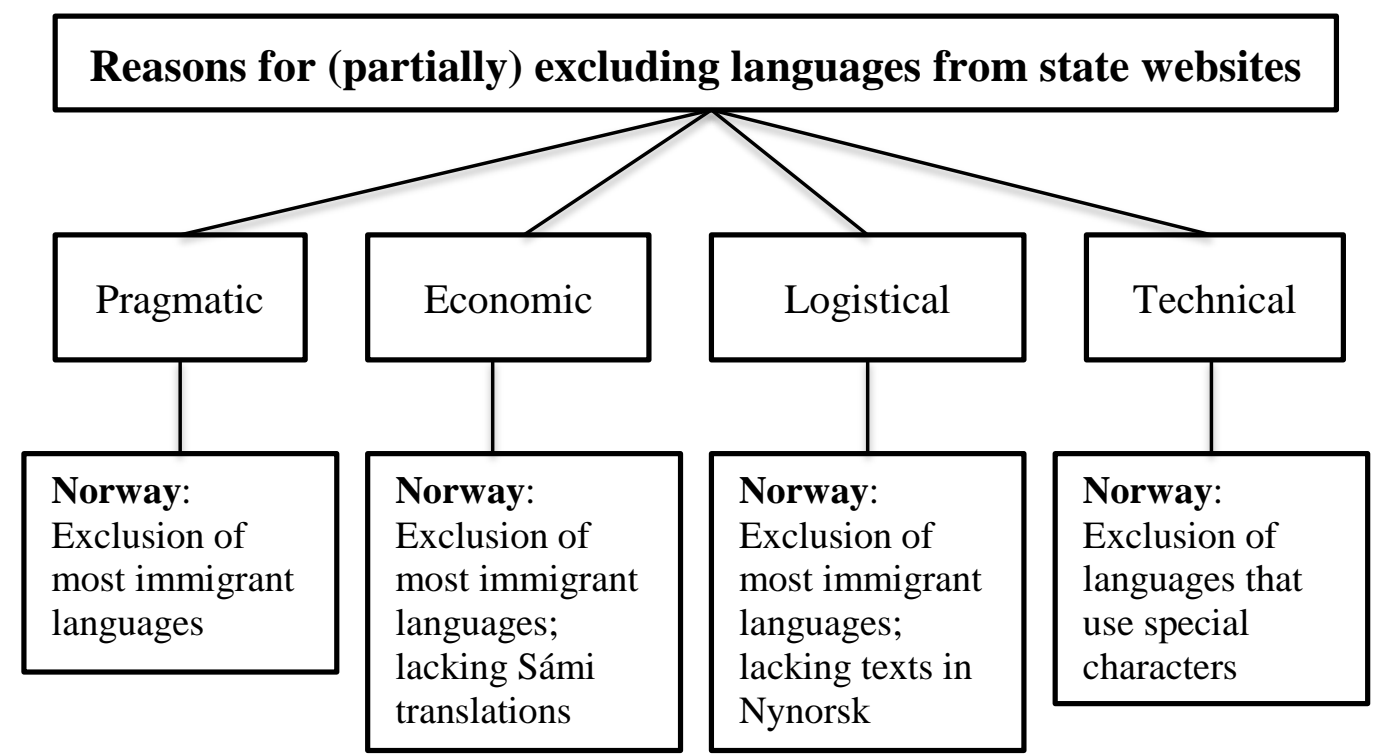

Figure 2. Overview of the reasons provided by language managers in Norwegian state institutions in order to explain the absence of various languages from the institutional websites or limited translations into various languages.

(f) Pragmatic reasons refer to the 'uselessness' of translating a state website into a certain language. In my material, the language managers used this type of justification most often when explaining the absence of various immigrant languages from state websites. Such explanations 
were often based on the claim that online was not the best mode for reaching some linguistic groups. The participants frequently mentioned that communication with groups that do not receive linguistic support online takes place through interpreting, face-to-face communication, and telephone service. This includes communication with those who are illiterate or are not able to use a computer. In addition to this, immigrants are expected to get help from family and friends who already reside in Norway and who have some command of either Norwegian or English. The participants also mentioned other alternative information sources for immigrants, such as embassies, churches, discussion forums, and Facebook.

It could perhaps be argued that such individualization of different linguistic groups is used in order to justify keeping the immigrant languages out of the 'shiny' website. Interestingly, a tension between the explanation for omitting immigrant languages from the website of the Norwegian Directorate of Immigration and real-life practices can be illustrated by an offline information campaign by the institution in 2015. The campaign made use of posters in various languages (Arabic, English, Persian, Russian, and Somali) about aid for migrants' voluntary return to their homeland. The posters were positioned in central locations in the capital, Oslo, and read as follows: 'Help with return to homeland. Hand in application now. New rules from the $1^{\text {st }}$ of September' (my translation). However, the website of the institution was the only contact method listed, and no phone number or address was provided. The only language from the ones used in the campaign, which was indeed also used on the website of the institution, was English.

(g) Economic reasons. This category includes the explanations about the absence of a language from a state website due to budgetary considerations. As pointed out by Gazzola (2006; see also Spolsky, 2009, p. 212), efficiency and cost may work in favor of a reduction in multilingualism in institutional communication. The participants in this study used the economic argument in order to justify the lack of translations into immigrant languages, as well as incomplete translations into Sámi. Such market-based justifications create, maintain, and reinforce a hierarchy of languages, where immigrant and indigenous minority languages remain at the bottom.

Hvis vi skulle ha ambisjon om å hatt tjuefire språk da, så ville det ha kosta veldig mye, vedlikehold ja.

If we were to have an ambition to have twenty-four languages, it would have cost very much, maintenance yes. (Labour and Welfare Administration) 
Og da er det jo kost-nytte vurdering for oss på om vi skal bruke veldig mange, hundre tusen kroner, på å oversette det når på en måte behovet er som det er.

And then there is a costs-benefits assessment for us about whether we shall use very many, hundred thousand crowns, on translating it [the Sámi website] when the need is sort of as it is. (Tax Administration)

Although multilingual production and dissemination of texts is much cheaper over the Internet than in more traditional media, it can indeed quickly become expensive to maintain a fully functioning multilingual website. However, the economic argument should only be accepted at face value, as 'the perception of how expensive a service is depends on the subjective value that the observer or the society attributes to it' (Gazzola, 2006, p. 400). The fact that a service is costly does not mean that it is de facto too expensive (Grin, 1997, p. 4), but rather that it is not prioritized within a given framework. Importantly, language legitimation and its positioning on the linguistic market (Bourdieu, 1991) take place to a large degree through the institutions of the state. The visible absence of a language from state communication can therefore affect its positioning in the society more broadly.

Finally, it should be pointed out that Norwegian state institutions are investing a lot of money into 'plain language' (klarspråk in Norwegian) and 'universal design' (universell utforming in Norwegian). The plain language project aims to make the texts available in Norwegian and English as user-friendly, and as clear and simple to understand as possible. There is thus a clear tendency for a prioritization of making the information in the majority languages as 'simple' as possible rather than investing into translation into minority languages. The presumed goal behind this communication strategy can be seen as online information provision to as broad a base of individuals as possible, but only to those who know Norwegian or English. This points to an expectation that immigrants should speak one of these languages if they are living in Norway and reinforces the idea of the nation state with one national language, together with English as the lingua franca.

(h) Logistical reasons are based on explanations involving the lack of a workforce necessary to manage the translations. This argumentation was mostly used to explain the absence of immigrant languages due to the challenges connected to managing large portals with tens of 
thousands of pages, and due to the absence of sufficient multilingual competence inside the institutions. As the participant in the Directorate of Immigration explained:

Vi ser at det er så uendelig mange språk vi forholder oss til, sånn at hvis vi skulle ha hatt alt på alle ulike språk, det ville vært helt uoverkommelig, ikke sant.

We see that there is such an infinite number of languages that we relate to, so that if we were to have everything in all the different languages, this would be quite insurmountable, right.

Logistical reasons were also mentioned in order to explain why the presence of Nynorsk on state websites was less than the $25 \%$, which is required by the law:

Vi har vel ikke tjuefem prosent nynorsk, for selv om vi oversetter en del, så $\varnothing$ ker jo ofte bokmålstekstene enda mer. [...] Det er staten som bestemmer og så prøver vi å nå opp til det, men lykkes dessverre ikke alltid helt, for at det $\varnothing$ kes alt for mye.

Well, we don't have twenty-five percent in Nynorsk because even though we translate quite a lot, the amount of texts in Bokmal often increases even more. [...] It's the government who decides, and then we try to reach up to it but unfortunately do not always succeed because it increases too much.

As already mentioned above in the discussion of 'legal' reasons, such an attitude demonstrates a low prioritization of Nynorsk in the state institutions, and an attitude of seeing the required presence of Nynorsk more as a burden than as 'a resource' (Ruíz, 1984). However, the 'logistical' argumentation was most broadly used in order to explain the removal of immigrant languages from the revised and updated version of the institutions' websites, all of which were launched around the time of the interviews. It should be pointed out, though, that the information in immigrant languages on the previous versions of the websites was highly limited, often consisting of only a couple of links or a very short text (see Berezkina, 2016). The effort of maintaining one or two pages with key information for immigrants is not comparable to the logistical challenges of keeping a fully functioning language version of a website updated. Therefore, the reasoning based on the logistical challenges of maintaining a multilingual website should be seen from a critical stance: similarly to the economic argument, we are here dealing with a lack of prioritization regarding certain languages, rather than objective constraints.

(i) Technical reasons. This category comprises explanations based on reference to the difficulties of processing special characters by the software used by the institutions, in order to justify the absence of a language or lacking translations. The technical argument was used by the 
Norwegian participants when they explained the difficulties of creating and maintaining a functioning website in immigrant languages. In addition, technical challenges in managing a website in Sámi were mentioned in connection to processing Sámi diacritics and special letters in databases. This is how the participant in the Tax Administration explained this matter:

Og så er det en del problematikk knyttet til tekniske løsninger, altså innrapporteringsløsninger hvor det er en del tegn man ikke håndterer, sånn som for samisk. [...] Og det er noe man ser i større og større grad, også i IT-sammenheng, at språk er en fordyrende og kompliserende faktor når du skal inn i de store systemene og det knytter seg til spesialtegn spesielt.

And then there are some issues related to technical solutions, that is solutions for reporting where there are some symbols that are not possible to handle, like for Sámi [...]. And this is something that you see to a larger and larger degree, also in the IT context, that language is a costly and complicating factor when you enter the big systems, and it's especially connected to special characters.

It is important to understand 'the way in which hardware and software perform regulatory functions - whether mandated by legal authorities or not' (Mac Síthigh, 2015, p. 83). Online multilingual communication is mediated through technology and influenced both by the affordances and the constraints of various digital tools (Jones \& Hafner, 2012). Although many of the technical limitations (for example, in multilingual data processing and website layout in other than Roman alphabets that require non-ASCII ${ }^{\mathrm{i}}$ characters) have been overcome in the last decade, there are still software restrictions on the use of diacritics and other alphabets. Standardized hardware and software that are incompatible with special characters can therefore pose a threat to the use of some languages on state websites. However, not investing into the development of technical solutions for processing characters used in non-majority languages should also be seen as a matter of prioritization ultimately driven by language ideologies in state institutions.

\section{Discussion and conclusions}

Some of the categories derived from the interviews are similar to those proposed by Gazzola (2006) in regard to the management of multilingualism in the European Union. Gazzola has listed the variables at stake as those of legal, political, cultural, functional, and budgetary nature. The language managers assign different degrees of importance to these variables, creating different 


\section{DRAFT - Please do not cite}

'sets of priorities' (Gazzola, 2006, p. 400). In the Estonian case, the functional aspect appears to be the most important variable regarding the wide presence of Russian in the country's virtual public sector. Language managers in Norwegian state institutions, on the other hand, refer first and foremost to the legal reasons when explaining the presence of minority languages online.

The institutional actors treat various languages in very different ways in their explanations, and their justifications assume and reinforce a certain hierarchy of languages. This can be well illustrated by the Norwegian case, where the 'economic', 'technical' and 'logistical' arguments only refer to the use of minority languages. The language managers explain their choices in a factual way (referring to economic, practical, legal factors), but these choices may indicate broader deep-seated ideologies around languages in the nation-state. 'Common sense' and pragmatics drive the justification but this seems to reflect the idea that multilingualism is problematic ("costly and complicating'). Immigrant minority languages are consistently positioned at the bottom of linguistic hierarchies (Extra \& Gorter, 2008; Liddicoat, 2013). This is well shown in the participants' explanations, which treat these languages more or less as 'a problem' (Ruíz, 1984). When the language policy actors explain away the absence of immigrant languages on state websites, they contribute to the delegitimation of certain sociolinguistic phenomena in the public sector, and to the non-recognition and non-representation of crucial multilingual practices (Duchêne, Moyer, \& Roberts 2013, p. 8). In this way, while virtual spaces allow for an increasing linguistic heterogeneity, the Internet can also be a mechanism to reinforce and strengthen homogeneity (Berezkina, 2016; Phyak, 2015).

The case of Russian on public sector websites in Estonia, on the other hand, demonstrates how multilingual practices that are not officially supported by state legislation can nevertheless be well accommodated by the institutions of the state. There is thus a significant contrast between official policies and real-life practices: despite the officially monolingual focus of the Estonian legislation, the institutional reality supports public multilingualism, at least in the virtual public sector. The extent to which a language is institutionalized can have a significant influence on the status attached to this language (May, 2015). The way the participants in this study supported the use of Russian on state websites indicates that the use of Russian in the Estonia's virtual public sector is more or less normalized. At least for state employees who are aware of the communicational needs with the broader public, the Russian language appears to be a valued resource. 
Finally, the use of certain languages in state communication is highly unlikely to be considered from such aspects as the economic or logistical challenges. A good example of this is the use of English, which has a powerful position in the 'constellation of languages' (Extra \& Gorter, 2008). Both in the Estonian and the Norwegian case, the widespread use of English on state websites was not questioned even once by the language managers. This demonstrates how normalized the presence of this 'hypercentral' (De Swaan, 2001) lingua franca has become in globalized countries like Norway and Estonia, and especially in cyberspace.

As the interview data show, institutional actors bring in a multiplicity of reasons in order to explain the prioritization of certain languages over others in online state communication. The covert language policy on institutional websites finds itself at the interface of overt policy statements which are influenced by political and governmental interests, and more covert considerations inside the institutions (Schiffman, 1998; Shohamy, 2006), which are based on the more locally situated needs, beliefs, and experiences. As suggested by numerous scholars (e.g. Ball 2008; Barakos 2016; Sperling 2009), language policy research should thus focus not only on the objects, products or outcomes, but also on the processes and practices related to their creation. As was demonstrated in this article, while official policies naturally have a large influence on the way multilingualism is managed in the institutions of the state, there are also significant other factors that come into play. Investigating the motivations behind language management helps to shed light on language policy as a complex process.

\section{Acknowledgement}

I would like to thank my PhD supervisors Helen Kelly-Holmes, Aneta Pavlenko and Unn Røyneland, as well as my wonderful colleagues at MultiLing for their feedback on an earlier draft of this article. I am also grateful to the two anonymous reviewers for their comments and suggestions.

\section{Funding}

This work was partly supported by the Research Council of Norway through its Centres of Excellence funding scheme, project number 223265. 


\section{Notes on contributor}

Maimu Berezkina is a PhD candidate at the Center for Multilingualism in Society across the Lifespan (MultiLing) at the University of Oslo. In her doctoral project she is researching multilingualism in the increasingly digitised public services of Estonia and Norway. Berezkina holds a specialist degree in Norwegian Linguistics and Literature from the State University of St. Petersburg, Russia, and a Master's degree in Scandinavian Linguistics from the University of Oslo. Her research interests include language policy and planning, multilingual websites, linguistic landscapes, and onomastics.

\section{References}

Androutsopoulos, J. (2009). Policing practices in heteroglossic mediascapes: A commentary on interfaces. Language Policy, 8(3), 285-290.

Baldauf Jr, R. B. (2006). Rearticulating the case for micro language planning in a language ecology context. Current Issues in Language Planning, 7(2-3), 147-170.

Ball, S. (2008). The education debate. Bristol: Policy Press.

Barakos, E. (2012). Language policy and planning in urban professional settings: Bilingualism in Cardiff businesses. Current Issues in Language Planning, 13(3), 167-186.

Berezkina, M. (2016). "Language is a costly and complicating factor": A diachronic study of language policy in the virtual public sector. Language Policy. doi:10.1007/s10993- 016-9422-2

Berezkina, M. (2017). Russian in Estonia's public sector: "Playing on the borderline" between official policy and real-life needs. International Journal of Bilingual Education and Bilingualism, 20 (4), 417-427.

Blackledge, A. (2005). Discourse and power in a multilingual world. Amsterdam: John Benjamins Publishing.

Blommaert, J, Kelly-Holmes, H., Lane, P., Leppänen, S., Moriarty, M., Pietikäinen, S., \& Piirainen-Marsh, A. (2009). Media, multilingualism and language policing. Language Policy, 8, 203-207.

Bourdieu, P. (1991). Language and Symbolic Power. Cambridge: Harvard University Press. 
Central Government Communication Policy. (2009). Retrieved from https://www.regjeringen.no/en/dokumenter/central-government-communication-policy/id582088/

De Swaan, A. (2001). Words of the World: The Global Language System. Cambridge: Polity Press.

Duchêne, A., Moyer, M., \& Roberts, C. (2013). Language, Migration, and Social Inequalities. Multilingual Matters.

Dörnyei, Z. (2007). Research methods in applied linguistics: Quantitative, qualitative, and mixed methodologies. Oxford: Oxford University Press.

European Commission. (2016). Retrieved from https://ec.europa.eu/digital-singlemarket/en/progress-country

Extra, G., \& Gorter, D. (2008). The constellation of languages in Europe: An inclusive approach. In G. Extra \& D. Gorter (Eds.), Multilingual Europe: facts and policies (pp. 3-60). Walter de Gruyter.

Gazzola, M. (2006). Managing multilingualism in the European Union: Language policy evaluation for the European Parliament. Language Policy, 5(4), 395-419.

Grepstad, O. (2015). Language facts 2015. A story about languages in Norway and the world through 800 tables. Nynorsk kultursentrum. (In Norwegian)

Grin, F. (1997). Managing European multilingualism: an economic approach to the problem of choice. Sociolinguistica, 11, 1-15. (In French)

Hornberger, N. H., \& Johnson, D. C. (2007). Slicing the onion ethnographically: Layers and spaces in multilingual language education policy and practice. Tesol Quarterly, 509-532.

Indrebø Ims, I. (2007). It is us who decide the way people speak and write. A study of Norwegian newspapers' normative principles and practice regarding language (Unpublished master's thesis). University of Oslo. (In Norwegian)

Irvine, J. T., \& Gal, S. (2000). Language ideology and linguistic differentiation. In P. Kroskrity (Ed.), Regimes of language (pp. 35-83). Santa Fe: School of American Research Press.

Jernudd, B. H., \& Neustupný, J. V. (1987). Language planning: for whom. In Proceedings of the international colloquium on language planning (pp. 69-84). Québec: Les Presses de l'Université Laval.

Johnson, D. C. (2011). Critical discourse analysis and the ethnography of language policy. Critical discourse studies, 8(4), 267-279. 
Johnson, D. C. (2015). Intertextuality and Language Policy. In F.M. Hult \& D.C. Johnson (Eds.), Research methods in language policy and planning: A practical guide (pp. 166-180). Hoboken, NJ: John Wiley \& Sons.

Johnson, D. C., \& Johnson, E. J. (2015). Power and agency in language policy appropriation. Language Policy, 14(3), 221-243.

Jones, R. H., \& Hafner, C. A. (2012). Understanding digital literacies: A practical introduction. Routledge.

Kelly-Holmes, H. (2014). Linguistic fetish: The sociolinguistics of visual multilingualism. In D. Machin (Ed.), Visual Communication (pp. 135-151). Berlin: De Gruyter.

Kochenov, D. \& de Varennes, F. (2015). Language and Law. In F.M. Hult \& D.C. Johnson (Eds.), Research methods in language policy and planning: A practical guide Research (pp. 56-66). Hoboken, NJ: John Wiley \& Sons.

Koskinen, K. (2013). Social media and the institutional illusions of EU communication. International Journal of Applied Linguistics, 23(1), 80-92.

Laakso, J., \& Sarhimaa, A. (2016). Towards Openly Multilingual Policies and Practices: Assessing Minority Language Maintenance Across Europe (Vol. 11). Multilingual Matters.

Language Act. (2011). Retrieved from www.riigiteataja.ee/en/eli/506112013016/

Lenihan, A. (2013). The Interaction of Language Policy, Minority Languages and New Media. A Study of the Facebook Translations Application (Unpublished doctoral dissertation). University of Limerick.

Liddicoat, A. J. (2013). Language-in-education policies: The discursive construction of intercultural relations (Vol. 153). Multilingual Matters.

Mac Síthigh, D. (2015). Because the computer speaks English? Language rights and digital media. Journal of Media Law, 7(1), 65-84.

May, S. (2015). Language rights and language policy: addressing the gap (s) between principles and practices. Current Issues in Language Planning, 16(4), 355-359.

McCarty, T.L. (Ed.) (2011). Ethnography and language policy. London: Routledge.

Mæhlum, B. (2007). Confrontations: When languages meet. Oslo: Novus Forlag. (In Norwegian)

Mållova. (1980). Retrieved from https://lovdata.no/dokument/NL/lov/1980-04-11-5

Ministry of Culture. (2014). The Strategy of Integration and Social Cohesion in Estonia 2020. Retrieved from http://www.kul.ee/et/valdkondlik-arengukava-loimuv-eesti-2020 (In Estonian) 
Nekvapil, J. (2006). From language planning to language management. Sociolinguistica, 20, 92104.

Nekvapil, J., \& Sherman, T. (2013). Language ideologies and linguistic practices: The case of multinational companies in Central Europe. In E. Barát, P. Studer \& J. Nekvapil (Eds), Ideological conceptualizations of language: Discourses of linguistic diversity (pp. 85-117).

Nekvapil, J., \& Sherman, T. (2015). An introduction: Language management theory in language policy and planning. International Journal of the Sociology of Language, 2015 (232), 1-12.

Pennycook, A. (2014). The cultural politics of English as an international language. Routledge.

Phyak, P. (2015). (En) Countering language ideologies: language policing in the ideospace of Facebook. Language Policy, 14(4), 377-395.

Pietikäinen, S., \& Kelly-Holmes, H. (2013). Multilingualism and the periphery. Oxford University Press.

Rannut, M. (2008). Estonianization Efforts Post-Independence. International Journal of Bilingual Education and Bilingualism 11(3-4), 423-439.

Ricento, T. K., \& Hornberger, N. H. (1996). Unpeeling the onion: Language planning and policy and the ELT professional. Tesol Quarterly, 30(3), 401-427.

Ruíz, R. (1984). Orientations in Language Planning. NABE Journal 8 (2): 15-34.

Røyneland, U. (2013). Norwegian language reforms in the 21st century. In T. Lohndal (Ed.), In search of universal grammar: From old Norse to Zoque (pp. 53-76). Amsterdam: John Benjamins.

Sameloven. (1987). Retrieved from https://lovdata.no/dokument/NL/lov/1987-06-12-56 (In Norwegian)

Sanden, G. R. (2016). Language management $\times 3$ : A theory, a sub-concept, and a business strategy tool. Applied Linguistics, 37(4), 520-535.

Schiffman, H. F. (1998). Linguistic culture and language policy. Psychology Press.

Shohamy, E. G. (2006). Language policy: Hidden agendas and new approaches. Psychology Press.

Siiner, M. (2016). University administrators as forced language policy agents. An institutional ethnography of parallel language strategy and practices at the University of Copenhagen. Current Issues in Language Planning, 17(3-4), 441-458. 
Simonsen Thingnes, J. (2015). Diversity in written Norwegian: language management, norm breaking and language attitudes (Unpublished master's thesis). University of Oslo. (In Norwegian)

Spolsky, B. (2004). Language policy. Cambridge University Press.

Spolsky, B. (2009). Language management. Cambridge University Press.

Statistics Estonia. (2016). Retrieved from http://www.stat.ee/en

Statistics Norway. (2016). Retrieved from https://www.ssb.no/en

Tollefson, J. W. (2006). Critical theory in language policy. An introduction to language policy: Theory and method, 42-59.

Vaara, E., Tienari, J., \& Laurila, J. (2006). Pulp and paper fiction: On the discursive legitimation of global industrial restructuring. Organization studies, 27(6), 789-813.

Verschik, A. (2005). The language situation in Estonia. Journal of Baltic Studies, 36(3), 283-316.

\footnotetext{
${ }^{\mathrm{i}}$ ASCII stands for American Standard Code for Information Interchange, which does not allow computing in nonRoman alphabets.
} 